\title{
Service Quality Level as the Determinant of Consumer Emotional Loyalty and Fantasy in South Africa's Pick \& Pay Chain Stores
}

\author{
Richard Chinomona1 \\ Maxwell Sandada \\ Vaal University of Technology, South Africa \\ 1E-mail: rchinos@hotmail.com
}

\author{
Doi:10.5901/mjss.2013.v4n3p579
}

\begin{abstract}
Despite the increase in research focusing on service level in retailing sector, there seem to be lack of studies that have investigated the influence of service quality level on customer emotional loyalty and fantasy in the African retailing context. Therefore, using a data set of 151 from athletes in Gauteng Province of South Africa, this study examines these relationships. All the posited two hypotheses are supported. The results indicate that retailer service level has positive and significant influence on consumer emotional loyalty and consumer fantasy. The research paper discusses both academic and managerial implications of the results and future research directions are suggested.
\end{abstract}

Keywords: Service quality level; Customer emotional loyalty; Customer fantasy; South Africa

\section{Introduction}

Given the dynamism and competitiveness that characterise today's business environment, practitioners and researchers generally agree that achieving customer satisfaction is now a necessary but not a sufficient condition to achieve competitive advantage. Rather, business enterprises need to ensure high levels of customer emotional loyalty (Kim \& Lee, 2010). Thus, instead of discrete transactions, it is now imperative and beneficial for business entities to pursue business strategies that ensure long term relationships which culminate in customer emotional loyalty (Zohra, 2011). This is so, because empirical evidence in the extant literature have consistently shown that emotional loyalty leads to customer retention, reduces marketing costs, provide business referrals and more so, loyal customers make more purchases over time (Sui \& Baloglu, 2003). Moreover, according to Mattila (2006), emotional bond emanating from loyalty to for instance, brands is needed in order to guarantee a business future repeated customer patronage. In this regard, business practitioners therefore need to pay attention to factors that enhance emotional loyalty (Loureiro, Ruediger \& Demetris, 2012) which is also reported to lead to customer fantasy - an extreme level of customer loyalty that results in a deep desire to repurchase the same preferred brand (Patwardhan \& Balasubramanian, 2011; Ltifi \& Gharbi, 2012). Emotional loyalty and customer fantasy can be deemed to be of paramount importance to retailers like Pick and Pay in Southern Africa which operates in a competitive environment dominated by other retailing giants such as Checkers and Makro. It is submitted therefore, in the current study that marketers may ensure customer continued repurchase by influencing the predictors of emotional loyalty to store brand and customer fantasy (Grisafe \& Nguyen, 2011). Surprisingly to note, there seem to be little research that has been done on antecedents of customer emotional loyalty and fantasy especially in the retail environment in Africa. Furthermore, the scant literature that exist on emotional loyalty and customer fantasy happen to be from the developed countries whose economic environments are different from developing and even emerging economies like South Africa. For results comparison and to expand the existing body of literature on customer emotional loyalty and fantasy predictors from an African perspective, the current study is warranted or perhaps long overdue.

In view of this identified research gap, the purpose of this study is to examine the influential role played by of the retailers' service quality level on the customer emotional loyalty and fantasy of customers in South Africa using Pick \& Pay Hypermarkets as a case in point. Exploring the influence of retailer's service level on customer emotional loyalty and fantasy will provide practical insights for retailers on how to satisfy customers in order to ensure that they are emotionally loyal and always imagine themselves buying from their stores. It is important for the retailers to have this knowledge as it helps them to ensure long term relationships with customers and hence achieve and sustain competitive advantages. The 
contributions of this study to the retail literature are that it retailer's service level as an important antecedent to both customer emotional loyalty and fantasy and hence develops a conceptual model that incorporates these variables.

The rest of the paper is arranged as follows: A theoretical review, the theoretical framework and hypotheses will firstly be presented. Thereafter the methodology, data analysis and conclusions are discussed. The final section presents the managerial implications, limitations and recommendations for future research.

\section{Literature Review}

\subsection{Customer perceived service quality level}

Superior customer service can be used as a tool to differentiate a business from competitors and to create and sustain competitive advantage (Ladhari, 2009). According to Kiran and Dilit (2011), service level performance is classified into environment quality (e,g access to quality of equipment), delivery quality (e.g customer relationships, personalisation and customer service quality), and outcome quality (e,g reliability, functional and emotional benefits). The benefits of high levels of customer performance include high level of customer satisfaction, improved customer retention, positive word of mouth, reduced staff turnover, enlarged market share and increased profitability (Ladhari, 2009). Further, Allaway, Huddleston, Whipple and Ellinger (2011) assert that high levels of customer service are a result of pleasant experiences due to helpful, polite and friendly employees, adequate employees providing the service and service orientation by the store. Consistent with this idea, Thach and Olsen (2006) highlighted the importance of customer service in a winery environment by suggesting that employees should possess strong human relations skills such as greeting customers, developing rapport with customers, interact friendly with customers, thanking customers and inviting them to visit again.

According to Tanford, Raab and Kim (2012), the dimensions that are important in evaluating the service quality level of hotels are: friendliness of hotel staff, cleanliness, speed and efficiency of the service, property facilities quality, free extras such as newspapers, availability of business services, value for money and availability of special discounts. In the context of the automobiles industry, Koller, Floh and Zauner (2011), identified customer service dimensions such as reliability of the cars, good car performance, fair car prices, the cars being environmentally friendly. Examining the winning strategies for mobile carries, Lim, Widdows and Park (2006) identified the dimensions that customers of mobile phones use to evaluate the service level such as the price level, network quality, messaging services, entertainment services, provision of location/map/directions services, billing system and ability to fix problems. Hence a high level of perceived service performance enhances the service provider's competitiveness. To evaluate the service level, Gracia, Bakker and Grau (2011) identified five dimensions such as reliability, responsiveness, assurance, empathy, and tangibles.

\subsection{Emotional loyalty}

Emotional loyalty refers to the customer's strong attachment to a brand or to the service provider, and is commonly described as affective loyalty (Shoemaker \& Bowen, 2003). Kim and Lee (2010) define emotional loyalty as the satisfied customer's overall romance with a particular retailer or brand that is based on the pleasurable experience with that retailer or brand. Hartel and Bennet (2010) view emotional loyalty as positive feelings by a customer towards a retailer/brand that result in persistent purchase of that brand. Such bonds with brands are as a result of enjoyable employee-customer interaction and unique loyalty programmes (Shoemaker \& Bowen, 2003). The authors proceed to state that customers with high levels of emotional loyalty do not easily switch to other brands and they spread positive word of mouth. According to Loureiro, Ruediger \& Demetris (2012) a customer becomes emotionally brand loyal if the brand is perceived as wonderful, if it makes the customer to feel good, if it makes customers very happy, if the brand is a delight to customers and if customers are passionate about the brand. Ensuring high levels of customer emotional loyalty is thus critical as it is an effective way to realise committed and profitable customers repurchasing preferred brands (Grisafe \& Nguyen, 2011). Tanford, Raab and Kim (2010) describe emotional loyalty as customer's attachment to a brand or provider. The authors further state that the customer strongly likes the brand, has a relationship with the brand, the brand means a lot to the customer and the customer feels to be part of a family of that brand. For Lee, Back and Kim (2009), customer emotional loyalty shows that customers are satisfied, pleased, excited and have pride with the service provided. In a retailing environment, emotionally loyal customers are those with strong, stable and durable bonds with a particular retailer and the bond results in exclusive purchases by customers and even if customers relocate, they still look for branches of the chosen retailer (Kim, Kim, Jolly \& Fairhurst, 2010). Consistent with this perspective, Hosany and 
Gibert (2010) identified the three dimensions of customer emotional loyalty, which are Joy, Love, and Passionate surprise.

\subsection{Customer fantacism}

Customer fantacism occurs when customers frequently experience day-dreams about the loved brand, when the brand often dominates the customer's thoughts, when the customer fails to control the thoughts they are obsessively on the brand and when the brand is always on the customer's mind (Patwardhan \& Balasubramanian, 2011). This shows that customer fantasy is an extreme level of loyalty and customers always imagine buying and using the brand. Ltifi and Gharbi (2012) view customer fantasy as an extreme level of customer loyalty that results in a deep desire to repurchase the same preferred brand. It means that it is loyalty that is beyond the emotional attachment. Customer fantasy is about customer imagery involving a particular brand or the tendency by customers to imagine themselves using a product which they adore, admire and would wish to possess (Song, Fiore \& Park, 2007). This view is consistent with Kim (2010) who suggested that customers with such intense loyalty have a powerful affective response that include passion for the store and a declaration of deep love for the brand or provider. In that vein, Song et al. (2007) state that customer fantasy is a pleasurable mental imagery that is formed after customer's satisfying experiences with the brand.

\section{Conceptual Model and Hypothesis Development}

Figure 1 shows the conceptual model depicting the three variables. The links among the variables are as follows: Due to high service quality level provided, customers enjoy the shopping experiences to such an extent that they have a desire to have a long term relationship with the store and eventually triggering their emotional loyalty to the store and its brands. In addition to that, as a result of customer emotional loyalty the customers may end up in a state of fantasy - strong passionate love for the store and its brands. The development of the hypotheses is discussed in the subsequent sections

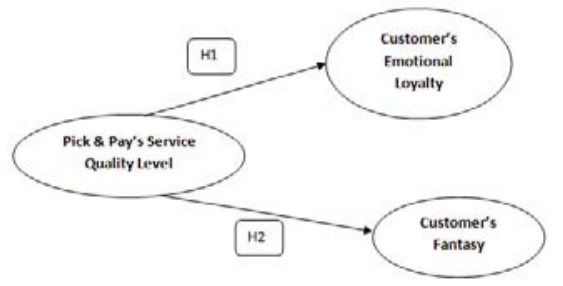

Figure 1: Conceptual Framework

\subsection{Service quality level and Customer's emotional loyalty}

According to Grisafe and Nguyen (2011), superior customer service such as product quality, fulfilling promises, consistent performance, reasonable prices, warranties, product quality and being available to customers, are crucial in enhancing customer's emotional loyalty. Similarly a high level of customer service performance is associated with strong feelings towards the service provider (Lim. Widdows \& Park, 2006). A study of the connection between customer quality and loyalty by Gracia, Bakker and Grau (2011) confirmed the proposed hypothesis that high service level increases positive customer emotional loyalty. The further show that emotionally loyal customers spread positive word of mouth communication, and make repeat purchases. Ranganathan, Madupu and Brooks (2013) endorsed the view that improved customer service level positively influences the customer's emotional loyalty. The authors state that the more customers experience satisfactory service performance, the more is their level of emotional loyalty. In the same vein, Thach and Olsen (2006) found that high levels of customer service correlate positively with the customer's emotional loyalty. Furthermore, the conclusion from Hosay and Gilbert's (2010) study of tourists' emotional experiences toward holiday destinations suggested that tourists emotional experiences are a result of satisfaction from the customer service performance provided. The view is also supported by Orth, Limon and Rose (2010) who found that customer's attachment to brand is stronger if the service is so high that it arouses customer pleasure, happiness and satisfaction. Lee, Back and Kim 92009) argued that if the service performance is of high quality, customers will appraise it and react with affect because it is enjoyable and pleasant. This shows that a high quality service performance enhances customer's emotional loyalty. Other scholars such as Kiran and Dilit (2011) also confirm the same relationship between customer service level and their emotional loyalty. Based on these arguments, it is proposed that: 
H1: The service quality level provided by the retailer has a positive influence on the customer's emotional loyalty

\subsection{Customer service and customer fantasy}

Ranganathan, Madupu, Sen \& Brooks (2013) examined the affective and cognitive antecedents of customer loyalty towards e-mail service providers and found that electronic service quality impacts positively on emotional loyalty. Along similar lines, the results of a path analysis of factors influencing customer loyalty of mobile phone service by Lee (2010) demonstrate that the customer service level provided significantly affected customer loyalty. This implies that customers who perceive a high level mobile phone service and likely to have emotional bonds with mobile phones and may also influence others to buy the same product. Therefore the level of service provided is important to retain customers and achieve and sustain competitive advantage (Lee, 2010). Gracia et al. (2011) found that high levels of customer service enhance customer happiness, pleasure, excitement and enthusiasm and this eventually leads to customer's extreme levels of loyalty. Customer service experience that is satisfying and provides pleasure, fun, and positive feelings will lead to customer fantasy that is created during the consumption experience (Song et al., 2007). Using respondents in holiday destinations setting, Hosay and Gilbert (2010) demonstrated that quality service performance significantly influences the customers' behavioural intentions. This means that a service that is excellently performed has an effect of strengthening the pleasure, fun and happiness that is experienced by the customers and hence their fantasy about the service provider. In the same line of thinking, Ladhari (2009) asserts that the more the customer experience quality service, the stronger is their loyalty and willingness to be associated with the brand. Such deep loyalty causes customers to have imaginations on their minds being associated with the provider or using the loved brand. This suggestion has found support from other scholars such as Hanzaee and Nasimi (2012) whose study of banking Iranian banking industry reported that improved customer service levels led to high levels of customer loyalty. If the customers experience satisfying customer service performance, they become very loyal and will be willing to repeat the same service experience and to refer other customers (Lee, et al., 2007). Therefore if customers experience the service performance with pleasure and happiness, it is logical to predict that quality customer service leads to customer imagery (fantasy). The study thus developed the following hypothesis:

$\mathrm{H} 2$ : The service quality level provided by the retailer has a positive influence on the customer's fantasy

\section{Research Methodology}

\subsection{Sample and data collection}

The target population for the study was South African consumer in Gauteng who purchased any consumer goods. The sampling unit was the individual consumer. A mall intercept survey was used. This method has the advantage of speed, is less costly and the researcher has control over respondent type. Four shopping malls in Vanderbijlpark were selected for this survey. Students from the Vaal University of Technology were recruited as research assistants to distribute and collect the questionnaires. Of the total of 170 questionnaires distributed, 151 usable questionnaires were retrieved for the final data analysis, representing a response rate of 89 per cent. To eliminate differences in response patterns due to different reference points, all respondents were prompted to answer the questionnaire with reference to non-durable consumer goods. The reason for selecting this category was that consumers frequently purchase these products. In this regard, the respondents were asked to identify a product category in which they had frequently made a purchase intention decision. Respondents were then asked to name a brand in that category and they were requested to think about that brand as they complete the entire questionnaire, guided by the research assistants.

\subsection{Measurement Instrument and Questionnaire Design}

Research scales were operationalized on the basis of previous work. Proper modifications were made in order to fit the current research context and purpose. "Service Quality Level" measure used three-item scales adapted from Fullerton (2005). "Emotional Loyalty" used five-item scale measure all adapted from Kim and Lee (2010) and Härtel and RussellBennett (2010). "Consumer fantasy" used a four-item scale measure adopted from Neil (2010). All the measurement items were measured on a five-point Likert-type scales that was anchored by $1=$ strongly disagree to $5=$ strongly agree to express the degree of agreement. Individual scale items are listed in Appendix 1.

\subsection{Respondent Profile}


Table 1 presents the description of the participants. The respondents were asked to report their demographic information, including gender, age, marital status and education. The respondents were predominantly females (57.6\%). The median age group of the respondent was that of less than 30 years (54.3\%). $57 \%$ of the respondents were single. About $71 \%$ of the respondents had either high school (43.7\%) or university level of education (27.2\%) and the remainder had primary school (19.9) or postgraduate level of education (0.09\%).

Table 1: Sample Demographic Characteristics

\section{Data Analysis}

\begin{tabular}{|c|c|c|}
\hline Gender & Frequency & Percentage \\
\hline Male & 64 & $42.4 \%$ \\
\hline Female & 87 & $57.6 \%$ \\
\hline Total & 151 & $100 \%$ \\
\hline Age & Frequency & Percentage \\
\hline$\leqq 30$ & 82 & $54.3 \%$ \\
\hline $31-60$ & 51 & $33.8 \%$ \\
\hline$\geqq 60$ & 18 & $11.9 \%$ \\
\hline Total & 151 & $100 \%$ \\
\hline Marital status & Frequency & Percentage \\
\hline Married & 65 & $43.0 \%$ \\
\hline Single & 86 & $57.0 \%$ \\
\hline Total & 151 & $100 \%$ \\
\hline Level of Education & Frequency & Percentage \\
\hline Primary School & 30 & $19.9 \%$ \\
\hline High School & 66 & $43,7 \%$ \\
\hline University & 41 & $27.2 \%$ \\
\hline Postgraduate & 14 & $0.09 \%$ \\
\hline Total & 151 & $100 \%$ \\
\hline
\end{tabular}

\subsection{Structural Equation Modelling Approach}

In order to statistically analyze the measurement and structural models, this study used Smart PLS software for Structural Equation Modeling (SEM) technique (Ringle, Wende \& Will 2005). In SEM, the measurement model refers to the linkages between the latent variables and their manifest variables and the structural model captures the hypothesized causal relationships among the research constructs (Chin \& Newsted, 1999). Unlike AMOS and LISREL which are covariancebased approaches, Smart PLS is a regression based technique that originates from path analysis. Smart PLS has emerged as a powerful approach to study causal models involving multiple constructs with multiple indicators (Chinomona \& Surujal, 2012). Smart PLS - a component-based method, has an ability to model latent constructs that are uncontaminated by measurement error under conditions of non-normality. It has the ability to handle complex predictive models in small-to-medium sample sizes. Since the current study sample size is relatively small (150) Smart PLS was found more appropriate and befitting the purpose of the current study. In this respect, Bootstrapping resampling method was used to test the statistical significance of the relationships. This procedure entailed generating 200 sub-samples of cases randomly selected, with replacement, from the original data. Below is Table 2, presenting evidence on the reliability and validity of the measurement model.

\subsection{Measurement Model}

To ensure convergent validity, the researcher checked if items loaded on their respective (a priori) constructs with loadings greater than 0.6 , while discriminant validity was checked by ensuring that there was no significant inter-research variables cross-loadings (Chin, 1998). As can be seen (Table 2), all items have loadings greater than 0.6 (i.e. ranging from 0.725 to 0.915 ), with no cross-loadings greater than 0.903 , while t-statistics derived from bootstrapping (200 resamples) suggest all loadings are significant at pb0.001. As such, this confirms that all the measurement items converged well on their respective constructs and therefore are acceptable measures.

Table 2. Accuracy Analysis Statistics 


\begin{tabular}{|c|c|c|c|c|c|c|c|c|}
\hline \multicolumn{2}{|c|}{ Research Construct } & $\begin{array}{c}\text { LV Index } \\
\text { Value }\end{array}$ & \begin{tabular}{|c|} 
R-Squared \\
Value
\end{tabular} & $\begin{array}{c}\text { Cronbach's } \alpha \\
\text { value }\end{array}$ & C.R. Value & $\begin{array}{l}\text { AVE } \\
\text { Value }\end{array}$ & Communality & $\begin{array}{l}\text { Factor } \\
\text { Loading }\end{array}$ \\
\hline \multirow{3}{*}{ SL } & SL1 & \multirow{3}{*}{4.347} & \multirow{3}{*}{0.000} & \multirow{3}{*}{0.839} & \multirow{3}{*}{0.903} & \multirow{3}{*}{0.757} & \multirow{3}{*}{0.757} & 0.845 \\
\hline & SL2 & & & & & & & 0.915 \\
\hline & SL3 & & & & & & & 0.849 \\
\hline \multirow{4}{*}{$\mathrm{CF}$} & CF1 & \multirow{4}{*}{4.350} & \multirow{4}{*}{0.969} & \multirow{4}{*}{0.845} & \multirow{4}{*}{0.896} & \multirow{4}{*}{0.684} & \multirow{4}{*}{0.684} & 0.733 \\
\hline & CF2 & & & & & & & 0.816 \\
\hline & CF3 & & & & & & & 0.896 \\
\hline & $\begin{array}{l}\text { CF4 } \\
\end{array}$ & & & & & & & 0.855 \\
\hline \multirow{5}{*}{ EL } & EL1 & \multirow{5}{*}{4.423} & \multirow{5}{*}{0.315} & \multirow{5}{*}{0.847} & \multirow{5}{*}{0.888} & \multirow{5}{*}{0.614} & \multirow{5}{*}{0.614} & 0.725 \\
\hline & EL2 & & & & & & & 0.807 \\
\hline & EL3 & & & & & & & 0.798 \\
\hline & EL4 & & & & & & & 0.752 \\
\hline & EL5 & & & & & & & 0.832 \\
\hline
\end{tabular}

Note: SL = Service Quality Level; CF = Consumer Fantasy; EL = Emotional Loyalty

According to Chin (1998), research variables should have an average variance extracted (AVE) of more than 0.5 and a composite reliability of more than 0.7 (convergent validity), and inter-construct correlations should be less than the square-root of the AVE (discriminant validity). As can be seen (Table 2), all constructs exceed these criteria, with AVE and CR generally equal or greater than 0.5 and 0.8 , respectively. Furthermore, as indicated in Table 3 , the square-root of the lowest AVE is 0.82 and is greater than the highest inter-construct correlation value (0.745). All in all, these results confirm the existence of discriminant validity of the measurement used in this study.

Table 3: Correlations between Constructs

\begin{tabular}{|l|c|c|c|}
\hline \hline \multicolumn{1}{|c|}{ Research Constructs } & SL & EL & CF \\
\hline Service Level (SL) & 1.000 & & \\
\hline Emotional Loyalty (EL) & 0.561 & 1.000 & \\
\hline Customer Fanaticism (CF) & 0.745 & 0.637 & 1.000 \\
\hline
\end{tabular}

Note: SL = Service Quality Level; CF = Consumer Fantasy; EL = Emotional Loyalty

\subsection{Path Model}

PLS also generates the path coefficients for the relationships modelled among the constructs. The significance of these coefficients was assessed using the bootstrap procedure (with 200 sub-samples) that provided the t-values for each path estimate. Figure 2 and Table 4 presents the results of the PLS analysis on the structural model along with the path estimates and t-values. Support for the study hypotheses, which are labelled on their corresponding paths in Figure 2 , could be ascertained by examining the directionality (positive or negative) of the path coefficients and the significance of the t-values. The standardized path coefficients are expected to be at least 0.2 , and preferably greater than 0.3 (Chin 1998).

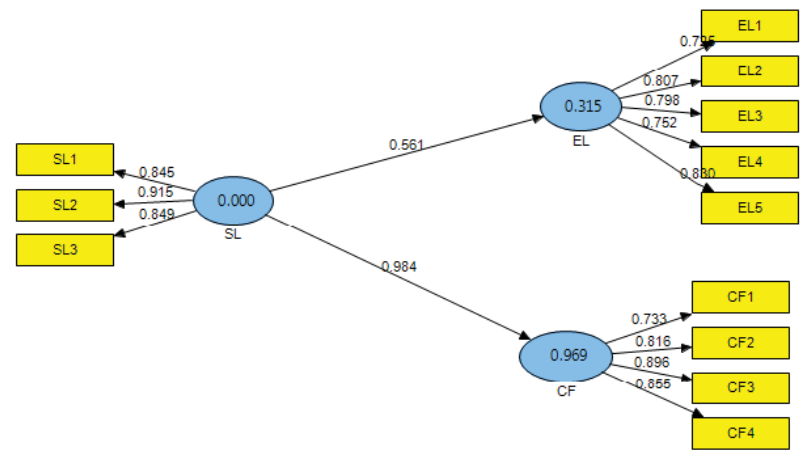

Note: SL = Service Quality Level; CF = Consumer Fantasy; EL = Emotional Loyalty

Figure 2: Measurement and Structural Model Results 
The results provide support for the proposed positive relationships between the two relationships (i.e. $\mathrm{H} 1$ and $\mathrm{H} 2$ ). Figure 2 and Table 4 provide the path coefficients for $\mathrm{H} 1$ and $\mathrm{H} 2$ (i.e. 0.561 and 0.969).

Table 4: Results of Structural Equation Model Analysis

\begin{tabular}{|l|c|c|c|c|}
\hline \hline \multicolumn{1}{|c|}{ Proposed Hypothesis Relationship } & Hypothesis & Path Coefficients & T-Statistics & Rejected / Supported \\
\hline Service Level (SL) $\rightarrow$ Emotional Loyalty (EL) & H1 & 0.561 & 21.969 & Supported \\
Service Level (SL) $\rightarrow$ Consumer Fantasy (CF) & H2 & 0.984 & 8.645 & Supported \\
\hline \hline
\end{tabular}

Note: SL = Service Quality Level; CF = Consumer Fantasy; EL = Emotional Loyalty

Overall, $\mathrm{R}^{2}$ for $\mathrm{EL}$ and $\mathrm{CF}$ in Figure 2, indicate that the research model explains more than $31 \%$ and $96 \%$ respectively of the variance in the endogenous variables. Following formulae provided by Tenenhaus, Vinzi, Chatelin \& Lauro, (2005), the global goodness-of-fit (GoF) statistic for the research model was calculated using the equation:

$$
\mathrm{GoF}=\sqrt{\overline{\mathrm{AVE}} * \overline{\mathrm{R}^{2}}}
$$

The calculated global goodness of fit $(\mathrm{GoF})$ is 0.66 , which exceed the threshold of $\mathrm{GoF}>0.36$ suggested by Wetzels, Odekerken-Schröder \& van Oppen (2009). Thus, this study concludes that the research model has a good overall fit.

\section{Discussion Of Results}

The results in Table 4 and Figure 2 provide support for the two hypotheses ( $\mathrm{H} 1$ and $\mathrm{H} 2$ ). Hypothesis 1 posited a positive relationship between service level and emotional loyalty. Consistent with $\mathrm{H} 1$, the result in Table 4 and Figure 2, indicates that there is a significant $(t=21.969)$ positive $(\beta=0.561)$ relationship between service level and emotional loyalty. Therefore, $\mathrm{H} 1$ is supported. Hypothesis 2 posited a positive association between service level and consumer fantasy. Hypothesis 2, results indicated that service level with consumer fantasy $(\beta=0.984)$ and the relationship is significant $(\mathrm{t}=$ 8.645). This is consistent with the prediction of $\mathrm{H} 2$ and is therefore supported. Thus, a higher level of service is associated with a high customer fantasy.

\subsection{Conclusion}

The purpose of this study was to investigate the influence of service level on customer emotional loyalty and customer fantasy. In particular, two hypotheses were postulated. To test the proposed hypotheses, data were collected from Gauteng Province in South Africa. The empirical result supported all the two posited research hypotheses in a significant way. This implies that the quality of service provision has a direct influence on the emotional loyalty of consumers and their fantasy.

\subsection{Implications of the study}

While there is an increased recognition of service quality as a critical aspect today's competitive business environment, the extant literature is replete with empirical evidence suggesting that customer emotional loyalty, and customer fantasy are related constructs of service quality. However, the current study was set to depart from this long held conventional wisdom and attempts to investigate the causal relationships between these constructs in service provision in the retailing industry. In particular, a successful attempt was made in this study to service quality as the predictor of customer emotional loyalty and customer fantasy. In addition to that, the current study investigate this contentious issues in an often most neglected research context - the African setting. Therefore, the findings of this empirical study are expected to provide fruitful new insights and implications to both academicians and retailing practitioners across the globe.

On the academic side, this study makes a significant contribution to the customer service and retailing literature by exploring the impact of service quality on the customer's emotional loyalty and fantasy in the context of South African one of the newly developed countries on the African continent. In particular, the current study findings provide tentative support to the proposition that service quality; customer emotional loyalty and customer fantasy should be recognized as antecedents and tools that precipitate repurchases intention in retailing.

On the practitioners' side, important influential role of service quality on customer's emotional loyalty and their fantasy in an African context are highlighted. Therefore, this study for instance submits that retailing owners or managers seeking to find ways to attract and retain customers should begin to consider this behaviour not only as the interplay of 
service provision, customer emotional loyalty and customer fantasy but rather a behaviour that is precipitated by service level and then develops to emotional loyalty and fantasy.

\subsection{Limitations and Future Research}

Although this study makes significant contributions to both academia and practice, it was limited in some ways, and therefore some future research avenues are suggested. First, the data were gathered from Gauteng Province of South Africa and the sample size of 151 is relatively small. Perhaps, the results would be more informative if the sample size is large and data gathered from the other eight provinces of the country are included. Therefore, future studies may be conducted by using data from other provinces in South Africa. Second, perhaps too, future studies should not be limited to South Africa, but rather consider extending this research to other African countries such as Zimbabwe for results comparison. Future studies can also extend the current study by studying the relationships in the current conceptual model in other sectors of the economy. Above and beyond, this will immensely contribute new knowledge to the existing body of consumer purchase behaviour in the retailing industry literature in the African setting - a research context which happens to be neglected in academics.

\section{References}

Allaway, A.W., Huddleston, P., Whipple, J. \& Ellinger, A.E. 2011. Customer-based Brand Equity, Equity Drivers, and Customer Loyalty in the Supermarket Industry. Journal of Product and Brand Management, 20(3):190-204.

Chin WW \& Newsted PR 1999. Structural equation modeling analysis with small samples using partial least squares. In Rick Hoyle (ed). Statistical Strategies for Small Sample Research. Thousand Oaks, CA: Sage. pp. 307-341.

Chin WW 1998. Issues and opinion on structural equation modelling, MIS Quarterly, 22 (1), 7-16

Fullerton G 2005. The service quality-loyalty relationship in retail services: does commitment matter?Journal of Retailing and Consumer Services,12,99-111

Garcia, E., Bakker, A.B. \& Grau, R.M. 2011. Positive Emotions: The Connection Between Customer Quality Evaluations and Loyalty. Cornell Hospitalty Quartely, 52(4):458-465.

Grisaffe, D.B. \& Nguyen, H.P. 2011. Antecedents of Emotional Attachment to Brands. Journal of Business Research, 64:1052-1059.

Hanzaee, K.H. 7 Nasimi, M.A. 2012. Path Analysis of Perceived Service Quality, Satisfaction and Loyalty in the Banking Industry of Iran. Research Journal of Applied Sciences, Engineering and Technology, 4(10):1351-1358.

Hartel, C.E.J. \& Russell-Bennett, R. 2010. Heart versus Mind: The Functions of Emotional and Cognitive Loyalty. Australian Marketing Journal, 18:1-7.

Hosany, S. \& Gilbert, D. 2010. Measuring Tourists' Emotional Experience Toward Hedonic Holiday Destinations. Journal of Travel Research, 49(4):513-526.

Kim, H.Y., Kim, Y.K., Jolly, L. \& Fairhurst, A. 2010. The Role of Love in Satisfied Customers' Relationships with Retailers. The International Review of Retail, Distribution and Consumer Research, 20(3):285-296.

Kim, H.Y. \& Lee, M.Y. 2010. Emotional Loyalty and Share of Wallet: A Contingency Approach. Journal of Retailing and Consumer Services. 17:333-339.

Kiran, K. \& Diljit, S. 2011. Antecedennts of Customer Loyalty; Does Service Quality Suffice? Malaysian Journal of Library and Information, 16(2):95-113.

Kuusik, A. \& Varblane, U. 2009. How to Avoid Customers Leaving: The Case of the Estonian Telecommunication Industry. Baltic Journal of Management, 4(1):66-79

Ladhari, R. 2009.Service Quality, Emotional Satisfaction, and Behavioural Intentions:A Study in the Hotel Industry. Managing Service Quality,19(3):308-331.

Lee, H.S. 2010. Factors of Internet Banking and Commerce. Journal of Internet Banking and Commerce, 15(2): 1-14.

Lee, Y.K., Black, K.J. \& Kim, J.Y. 2009. Family Restaurant Brand Personality and its Impact On Customers's eMotion, Satisfaction and Brand Loyalty. Journal of Hospitality and Tourism Research, 33(3):305-328.

Lim, H., Widdows, R. \& Park, J. 2006. M-Loyalty: Winning Strategies for Mobile Carriers. Journal of Consumer Marketing, 23(4):208-218.

Loureiro. S.M.C., Ruediger, K.H. \& Demetris, V. 2012. Brand Emotional Connection and Loyalty. Journal of Brand Management:1-5.

Ltifi, M. \& Ghardi, J.E.2012.Satisfaction and Loyalty with the Tunisian Postal Services, International Journal of Humanities and Social Science,2(7): 178-189.

Mattila, A. 2006. How Affective Commitment Boosts Guest Loyalty (and Promotes Frequent-Guest Programmes). Cornell Hotel and Restaurant Administration Quarterly, 47(2):174-181.

Orth, U.R., Limon, Y. \& Rose, G. 2010. Store-Evoked Affect, Personalities, and Consumer Emotional Attachments to Brands. Journal of Business Research, 63:1202-1208.

Patwardhan, H. \& Balasubramanian, S.K. 2011. Brand Romance: A Complementary Approach to Explain Emotional Attachment Toward Brands. Journal of Product and Brand Management, 20(4):297-308.

Ranganathan, S.K., Madupu, V., Sen, S. \& Brooks, J.R. 2013. Affective and Cognitive Antecendents of Customer Loyalty Towards E-mail service providers. Journal of Services Marketing, 27(3):195-206.

Ringle CM, Wende S \& Will A 2005. SmartPLS 2.0 M3. Available at http:// www.smartpls.de. Accessed 23/03/2013

Shoemaker, S. \& Bowen, J.T. 2003. Loyalty: A Strategic Commitment. Cornell Hotel and Restaurant Administration Quartely, 47:31-46.

Song, K. \& Fiore, A.M 2007. Telepresence and Fantasy in Online Apparel Shopping Experience. Journal of Fashion Marketing and Management, 11(4):553570.

Sui, J.J. \& Baloglu, S. 2003. The Role of Emotional Commitment in Relationship Marketing: An Empirical Investigation of a Loyalty Model for Casinos. Journal of Hospitality and Tourism Research, 27(4):470-489.

Tanford, S., Raab, C. \& Kim, Y.S. 2012. Determinants of Customer Loyalty and Purchasing behaviour for full-service and limited-service hotels. International Journal of Hospitality Management, 31:319-328.

Thach, E.C. \& Olsen, J. 2006. The Role of Service Quality in Influencing Brand Attachments at Winery Visitor Centres. Journal of Quality Assurance in Hospitality and Tourism, 7(3):59-77.

Zohra, G. 2011. The Role of the Emotion Felt Towards a Brand in the Development of the Behaviour of Loyalty: An Application in the Sector of Mobile Phones in Tunisia. African Journal of Marketing Management, 3(8):168-177. 